\title{
Production of xylooligosaccharides and monosaccharides from poplar by a two-step acetic acid and peroxide/acetic acid pretreatment
}

\author{
Peiyao Wen ${ }^{1}$, Tian Zhang ${ }^{1}$, Jinye Wang ${ }^{1}, Z^{2}$ hina Lian ${ }^{2}$ and Junhua Zhang ${ }^{1,2^{*}}$ (1)
}

\begin{abstract}
Background: Populus (poplar) tree species including hybrid varieties are considered as promising biomass feedstock for biofuels and biochemicals production due to their fast growing, short vegetative cycle, and widely distribution. In this work, poplar was pretreated with acetic acid (AC) to produce xylooligosaccharides (XOS), and hydrogen peroxide-acetic acid (HPAC) was used to remove residual lignin in AC-pretreated poplar for enzymatic hydrolysis. The aim of this work is to produce XOS and monosaccharides from poplar by a two-step pretreatment method.

Results: The optimal conditions for the $A C$ pretreatment were $170^{\circ} \mathrm{C}, 5 \% \mathrm{AC}$, and $30 \mathrm{~min}$, giving a XOS yield of $55.8 \%$. The optimal HPAC pretreatment conditions were $60^{\circ} \mathrm{C}, 2 \mathrm{~h}$, and $80 \% \mathrm{HPAC}$, resulting in $92.7 \%$ delignification and $87.8 \%$ cellulose retention in the AC-pretreated poplar. The two step-treated poplar presented $86.6 \%$ glucose yield and $89.0 \%$ xylose yield by enzymatic hydrolysis with a cellulases loading of $7.2 \mathrm{~m} / \mathrm{g}$ dry mass. Very high glucose (93.8\%) and xylose (94.6\%) yields were obtained with $14.3 \mathrm{mg}$ cellulases/g dry mass. Both Tween 80 and $\beta$-glucosidase enhanced glucose yield of HPAC-pretreated poplar by alleviating the accumulation of cellobiose. Under the optimal conditions, $6.9 \mathrm{~g} \mathrm{XOS}, 40.3 \mathrm{~g}$ glucose, and $8.9 \mathrm{~g}$ xylose were produced from $100 \mathrm{~g}$ poplar.

Conclusions: The AC and HPAC pretreatment of poplar represented an efficient strategy to produce XOS and fermentable sugars with high yields. This two-step pretreatment was a recyclable benign and advantageous scheme for biorefinery of the poplar into XOS and monosaccharides.
\end{abstract}

Keywords: Poplar, AC pretreatment, HPAC pretreatment, Lignin removal, Xylooligosaccharides, Enzymatic hydrolysis

\section{Background}

Cellulosic biomass represents a renewable, low-cost resource that can be converted into biofuels and biochemicals $[1,2]$. Poplar, as a fast growing, widely distributed, short rotation period crop, is considered as a suitable feedstock for this process [3, 4]. Enzymatic hydrolysis of poplar for the production of fermentable sugars, a key step for biofuels and biochemicals production, has been extensively investigated and different

\footnotetext{
*Correspondence: junhuazhang@nwafu.edu.cn

${ }^{1}$ College of Forestry, Northwest A\&F University, 3 Taicheng Road, Yangling 712100, Shaanxi, China

Full list of author information is available at the end of the article
}

pretreatments, including ionic liquids, steam explosion, and acid/alkaline media, have been adopted to increase the accessibility of enzymes to polysaccharides [5-10]. These pretreatments are usually conducted with high temperature or long time [6]. Moreover, severe pretreatment could easily solubilize cellulose and xylan in poplar and made them hard to be recovered and utilized [7, 8 , 10]. Therefore, efficiently utilization of polysaccharides in poplar still remains a challenge.

Xylooligosaccharides (XOS), derived from xylan in lignocellulosic biomass by enzymatic and/or chemical hydrolysis, have important prebiotic properties and show great potential application in medicinal, food, and health fields [11]. Recently, co-production of functional 
xylooligosaccharides and fermentable sugars from lignocellulosic materials by autohydrolysis, alkaline, and acid pretreatments has been reported [11-16]. Acetic acid (AC) pretreatment offered a green approach to effectively convert corncobs, viscose fibers, and poplar to XOS and fermentable sugars [14-16]. It has been reported that a good XOS yield of $45.91 \%$ was obtained from corncob by $\mathrm{AC}$ pretreatment at $\mathrm{pH} 2.7$ and $150{ }^{\circ} \mathrm{C}$ for $30 \mathrm{~min}$ [14]. AC-pretreated poplar can produce a $36.0 \%$ XOS yield with $6.5 \% \mathrm{AC}$ at $172{ }^{\circ} \mathrm{C}$ for $27 \mathrm{~min}$ with a clear increase (from 28.3 to $51.0 \%$ ) of hydrolysis yield of AC-pretreated poplar by cellulases compared to poplar after autohydrolysis [15]. Normally, AC can be used to remove lignin with high temperature and high $\mathrm{AC}$ concentration [17]. However, after $6.5 \% \mathrm{AC}$ pretreatment at $170{ }^{\circ} \mathrm{C}$, the $\mathrm{AC}$ pretreated poplar had high lignin content $(>30 \%)$ [15]. A large amount of lignin in poplar is unfavorable for enzymatic hydrolysis [18]. Thus, it is necessary to probe an effective method to alleviate lignin inhibition or to remove lignin to increase cellulases accessibility to cellulose in AC-pretreated poplar.

In this work, $\mathrm{XOS}$ and monosaccharides were produced from poplar by a combination of $\mathrm{AC}$ and hydrogen-peroxide/acetic acid (HPAC) pretreatments and enzymatic hydrolysis. Effects of AC concentration, temperature, time on XOS yields were investigated. After that, the AC-pretreated solid residues were then subjected to the HPAC process to remove lignin, aiming at enhancing the hydrolyzability of cellulose in poplar. The effects of Tween 80 and $\beta$-glucosidase on the hydrolysis of HPAC-pretreated poplar were also probed.

\section{Results and discussion AC pretreatment Component analysis of AC-pretreated poplar}

In the pretreatment of poplar with water (autohydrolysis) for 10, 30, and $50 \mathrm{~min}$, the xylan content decreased from $17.4 \%$ to $16.5 \%, 11.0 \%$, and $8.4 \%$, respectively (Table 1 ). When the AC concentration was less than $5 \%$, very high glucan retention (>93\%) was observed and the contents of glucan and lignin increased due to the removal of xylan by $\mathrm{AC}$ pretreatment. The highest acid insoluble lignin content (36.1\%) was obtained from the poplar pretreated with $5 \% \mathrm{AC}$ for $50 \mathrm{~min}$. With the presence of $10 \% \mathrm{AC}$ at $170{ }^{\circ} \mathrm{C}$ for $10 \mathrm{~min}$, xylan and lignin were solubilized and the xylan and lignin removal increased from $6.8 \%$ and $0.3 \%$ to $40.2 \%$ and $6.0 \%$, respectively. The data indicated that $\mathrm{AC}$ pretreatment was more effective than autohydrolysis pretreatment in xylan and lignin removal [18]. After pretreatment with $10 \% \mathrm{AC}$ at $170{ }^{\circ} \mathrm{C}$ for $50 \mathrm{~min}$, the xylan content decreased to $3.2 \%$ with a xylan removal of $87.8 \%$ and a lignin removal of $11.9 \%$.
Table 2 shows that $5 \%$ AC pretreatment for $30 \mathrm{~min}$ gave the highest XOS yield (55.8\%), which was close to the yield of $51.5 \%$ (based on the xylan removed in pretreatment liquor) obtained in previous work [15]. However, the XOS yield from poplar was lower than that from corncob $(62.2 \%$, based on the xylan removed in pretreatment liquor) [14]. In this work, 5\% $\mathrm{AC}$ and $30 \mathrm{~min}$ was chosen as the optimal AC conditions because it gave the highest XOS yield (55.8\%) and acceptable loss of glucan (5.5\%). After the optimal AC pretreatment, about $12.4 \mathrm{~g}$ xylan was removed in the pretreatment liquor from $100 \mathrm{~g}$ poplar and $6.9 \mathrm{~g}$ XOS and $4.6 \mathrm{~g}$ xylose were produced in the AC pretreatment liquor. The results indicated that some high DP oligomers were produced in AC pretreatment of poplar. The AC-pretreated poplar with optimal conditions contained 54.9 g glucan, $6.7 \mathrm{~g}$ xylan and $33.4 \mathrm{~g}$ lignin per $100 \mathrm{~g}$ of non-pretreated poplar, which corresponded to the removal of $71.3 \%$ of the original xylan and $4.9 \%$ of the original lignin (Table 1 ).

\section{Characterization of AC-pretreated poplar}

The XRD patterns of the non-pretreated and pretreated poplar samples showed that the crystalline structure of the cellulose in these poplar materials was unchanged after AC pretreatment and could be assigned as cellulose I (Additional file 1: Fig. S1) [19]. The crystallinity index (CI) indicates the relative amount of crystalline cellulose in the sample, and Table 3 demonstrated that the CI values of the poplar increased from $47.1 \%$ of raw poplar to $55.2 \%$ of AC-pretreated poplar (5\% AC, $170{ }^{\circ} \mathrm{C}, 30 \mathrm{~min}$ ). The AC pretreatment resulted in the increase in CI was due to the removal of xylan (Table 1). The removal of xylan can also be observed by FTIR spectroscopy (Additional file 1: Fig. S2). After the AC pretreatment, both the peak related to $\mathrm{C}=\mathrm{O}$ groups associated with ester linkages between the lignin and hemicellulose at $1720 \mathrm{~cm}^{-1}$ and the peak due to the $\mathrm{C}-\mathrm{O}-\mathrm{C}$ stretching of the acetyl groups in hemicellulose at $1245 \mathrm{~cm}^{-1}$ decreased in intensity [20]. At the same time, the absorption bands at $1300-1600 \mathrm{~cm}^{-1}$ related to lignin increased in strength. The data here supported the selective removal of xylan by the AC pretreatment (Table 1).

The surface chemistry of biomass can be investigated by XPS [21] and a high O/C reflects higher cellulose and/ or hemicellulose content, while a low $\mathrm{O} / \mathrm{C}$ suggests the presence of more lignin [22]. The surface proportions of $\mathrm{C}$ and $\mathrm{O}$ atoms in the non-pretreated and pretreated poplar are provided in Table 3. In AC-pretreated poplar samples, C1, C2, and C3 carbon peaks were observed (Additional file 1: Fig. S3), which were in good agreement with the results obtained from corn stover [23, 24]. With the increase in pretreatment time from 10 to $50 \mathrm{~min}$, the $\mathrm{O} / \mathrm{C}$ ratio of $\mathrm{AC}$-pretreated poplar increased 
Table 1 Chemical compositions of poplar after AC pretreatment at $170^{\circ} \mathrm{C}$, expressed as percentage of dry mass (DM)

\begin{tabular}{|c|c|c|c|c|c|c|c|c|c|c|}
\hline \multirow{2}{*}{$\begin{array}{l}\text { AC } \\
\text { concentration }\end{array}$} & \multirow{2}{*}{$\begin{array}{l}\text { Treatment } \\
\text { time (min) }\end{array}$} & \multirow{2}{*}{$\begin{array}{l}\text { Severity } \\
\text { factor }\end{array}$} & \multirow{2}{*}{$\begin{array}{l}\text { Glucan } \\
\text { (\%) }\end{array}$} & \multirow{2}{*}{$\begin{array}{l}\text { Xylan } \\
(\%)\end{array}$} & \multirow{2}{*}{$\begin{array}{l}\text { Acid insoluble } \\
\text { lignin (\%) }\end{array}$} & \multirow{2}{*}{$\begin{array}{l}\text { Acid soluble } \\
\text { lignin (\%) }\end{array}$} & \multirow{2}{*}{$\begin{array}{l}\text { Solids recovery } \\
\text { (\%) }\end{array}$} & \multicolumn{3}{|c|}{ Removal } \\
\hline & & & & & & & & $\begin{array}{l}\text { Glucan } \\
(\%)\end{array}$ & $\begin{array}{l}\text { Xylan } \\
(\%)\end{array}$ & $\begin{array}{l}\text { Lignin } \\
(\%)\end{array}$ \\
\hline Raw & & - & $43.4 \pm 0.0$ & $17.4 \pm 0.2$ & $24.4 \pm 0.3$ & $3.5 \pm 0.3$ & - & - & - & - \\
\hline $0 \%$ & 10 & 3.1 & $43.9 \pm 0.1$ & $16.5 \pm 0.5$ & $25.1 \pm 0.0$ & $3.4 \pm 0.3$ & 98.1 & 0.8 & 6.8 & 0.3 \\
\hline $5 \%$ & 10 & 3.1 & $46.9 \pm 0.9$ & $14.8 \pm 0.2$ & $27.1 \pm 0.3$ & $3.0 \pm 0.3$ & 90.5 & 2.2 & 23.0 & 2.5 \\
\hline $10 \%$ & 10 & 3.1 & $52.3 \pm 0.1$ & $12.9 \pm 0.1$ & $29.9 \pm 0.2$ & $2.6 \pm 0.3$ & 80.7 & 2.7 & 40.2 & 6.0 \\
\hline $0 \%$ & 30 & 3.5 & $49.1 \pm 0.0$ & $11.0 \pm 0.2$ & $28.7 \pm 0.1$ & $2.7 \pm 0.3$ & 85.9 & 2.8 & 45.5 & 3.4 \\
\hline $5 \%$ & 30 & 3.5 & $54.9 \pm 0.4$ & $6.7 \pm 0.5$ & $33.4 \pm 0.5$ & $2.2 \pm 0.3$ & 74.7 & 5.5 & 71.3 & 4.9 \\
\hline $10 \%$ & 30 & 3.5 & $58.7 \pm 0.6$ & $5.1 \pm 0.4$ & $34.6 \pm 0.1$ & $2.0 \pm 0.3$ & 69.5 & 5.9 & 79.6 & 9.2 \\
\hline $0 \%$ & 50 & 3.8 & $53.6 \pm 0.3$ & $8.4 \pm 0.4$ & $32.6 \pm 0.1$ & $2.3 \pm 0.3$ & 77.0 & 4.8 & 62.8 & 3.7 \\
\hline $5 \%$ & 50 & 3.8 & $58.8 \pm 0.2$ & $4.3 \pm 0.4$ & $36.1 \pm 0.1$ & $2.0 \pm 0.3$ & 68.8 & 6.7 & 82.8 & 6.1 \\
\hline $10 \%$ & 50 & 3.8 & $57.6 \pm 0.1$ & $3.2 \pm 0.2$ & $35.6 \pm 0.1$ & $1.9 \pm 0.3$ & 65.6 & 12.9 & 87.8 & 12.0 \\
\hline
\end{tabular}

from 0.37 to 0.41 and $\mathrm{C} 1$ peak intensity reduced from 56.0 to $49.4 \%$, which indicated that surface lignin content decreased after $\mathrm{AC}$ pretreatment. The $\mathrm{O} / \mathrm{C}$ ratio of $\mathrm{AC}$ pretreated poplar was lower than that of raw poplar, possibly because of the removal of the extracts [21]. The C1 peak intensity of $10 \mathrm{~min}$ AC-pretreated poplar (56.0\%) was higher than non-pretreated poplar (54.0\%). The increase in $\mathrm{C} 1$ peak intensity indicated the increased surface lignin content. This result could be due to the lignin redeposition on the surface of poplar during AC pretreatment [22].

Hydrophobic interactions are regarded as the main driving force for the formation of non-productive binding between lignocellulose and cellulases [25]. The hydrophobicity values of the raw and pretreated poplar are presented in Table 3 and Additional file 1: Fig. S4. The hydrophobicity of the raw poplar was $0.37 \mathrm{~g} / \mathrm{L}$. As the AC treatment time increased from 10 to $50 \mathrm{~min}$, the hydrophobicity of the poplar reduced from 0.54 to $0.31 \mathrm{~g} / \mathrm{L}$. However, the hydrophobicity of $5 \% \mathrm{AC}$ and $30 \mathrm{~min}$ pretreated poplar was $0.49 \mathrm{~g} / \mathrm{L}$, which was still higher than that of the raw poplar. Hydrophobicity has been often characterized as a critical contributory factor to lignin inhibition of enzymatic hydrolysis [26] and cellulases adsorption onto lignin in pretreated substrates by hydrophobic interactions has been confirmed [25]. The higher hydrophobicity of AC-pretreated poplar indicated that the AC-pretreated poplar exhibited stronger cellulases adsorption capacity than the non-pretreated poplar [22].

The surfaces images of the raw and AC-pretreated poplar were characterized by SEM (Additional file 1: Fig. S5). The AC pretreatment resulted in less damage to the rigid structure of the raw poplar. Compared with the non-pretreated poplar, a plethora of spherical droplets was observed on the surfaces of the $5 \%$ and $10 \%$ AC-pretreated samples. These observations were in agreement with prior reports that the lignin droplets can be found on substrate after dilute acid pretreatment [27-30]. Lignin droplets probably led to a low hydrolysis yield of AC-pretreated poplar because the lignin droplets formed by acid pretreatment strongly inhibited cellulose hydrolysis in biomass by steric hindrance and non-productive adsorption of enzymes [31, 32].

\section{Enzymatic hydrolysis of AC-pretreated poplar}

Only $11.4 \%$ of glucose yield and $8.8 \%$ of xylose yield were obtained from the non-pretreated poplar with a cellulases loading of $28.6 \mathrm{mg} / \mathrm{g}$ DM. After pretreatment with $0 \% \mathrm{AC}$ (autohydrolysis) for 10 and $50 \mathrm{~min}$, glucose yields were $9.9 \%$ and $17.3 \%$, respectively (Fig. 1a). In the enzymatic hydrolysis of poplar pretreated by $10 \% \mathrm{AC}$ for $50 \mathrm{~min}$, glucose yield increased to $27.6 \%$ and xylose yield reached $43.1 \%$ (Fig. 1b). With the increase in cellulases dosage up to $85.8 \mathrm{mg}$ protein of cellulases/g DM, the glucose and xylose yields in AC-pretreated poplar $\left(5 \%, 170{ }^{\circ} \mathrm{C}, 30 \mathrm{~min}\right)$ were $29.1 \%$ and $40.3 \%$, respectively (Additional file 1: Fig. S6). The results here confirmed that hydrolysis yields of poplar pretreated by AC under the tested conditions were limited, which could be partially due to acetylation and the presence of high lignin content $(>25 \%)$ in the pretreated poplar $[18,33]$.

The 5\% AC-pretreated poplar had higher acetyl content (more than 5.5\%) than raw poplar (Table 3). It has been pointed out that pretreatment of lignocellulosic biomass with $\mathrm{AC}$ may result in the acetylation of its compounds such as cellulose and hemicellulose [31]. Enzymatic hydrolysis of the AC-pretreated poplar without any additional alkali pretreatment may not break the acetylated glucan and xylan and subsequently, affect their conversion to sugars [33]. In order to explore the effect of acetyl contents in AC-pretreated poplar on enzymatic hydrolysis, $1 \%(\mathrm{w} / \mathrm{v})$ sodium hydroxide was used to treat 
Table 2 The formations of xylose and XOS (DP 2-6) from poplar by the 0-10\% AC pretreatment for 10-50 min

\begin{tabular}{|c|c|c|c|c|c|c|c|c|}
\hline \multirow{2}{*}{$\begin{array}{l}\mathrm{AC} \\
\text { concentration } \\
(\%)\end{array}$} & \multirow{2}{*}{$\begin{array}{l}\text { Treatment } \\
\text { time }(\min )\end{array}$} & \multirow[t]{2}{*}{ Xylose (\%) } & \multicolumn{5}{|c|}{ Xylooligosaccharide (\%) } & \multirow{2}{*}{$\begin{array}{l}\text { XOS yield } \\
\text { (\%, DP 2-6) }\end{array}$} \\
\hline & & & Xylobiose & Xylotriose & Xylotetraose & Xylopentaose & Xylohexaose & \\
\hline 0 & 10 & 2.4 & 5.0 & 6.3 & 6.3 & 3.1 & 2.1 & 22.8 \\
\hline 5 & 10 & 9.1 & 4.3 & 3.8 & 5.0 & 2.6 & 3.1 & 18.8 \\
\hline 10 & 10 & 18.9 & 9.7 & 8.4 & 10.8 & 5.3 & 6.2 & 40.5 \\
\hline 0 & 30 & 5.6 & 4.2 & 4.9 & 3.9 & 4.7 & 5.2 & 22.9 \\
\hline 5 & 30 & 32.9 & 14.5 & 11.4 & 15.7 & 7.5 & 6.6 & 55.8 \\
\hline 10 & 30 & 43.8 & 15.7 & 7.9 & 10.0 & 3.6 & 2.8 & 40.0 \\
\hline 0 & 50 & 8.6 & 5.9 & 6.7 & 9.2 & 5.9 & 6.9 & 34.6 \\
\hline 5 & 50 & 43.6 & 13.8 & 8.3 & 10.4 & 3.7 & 2.8 & 39.0 \\
\hline 10 & 50 & 46.4 & 11.7 & 4.1 & 5.6 & 1.3 & 1.2 & 23.9 \\
\hline
\end{tabular}

The XOS yields were based on the AC post-hydrolysis of pretreatment liquor

Table 3 XPS, acetyl, hydrophobicity, and crystallinity index (\%) analysis of non-pretreated and 5\% AC-pretreated poplar

\begin{tabular}{llllllll}
\hline Treatment time & C1 (\%) & C2 (\%) & C3 (\%) & O/C & Acetyl (\%) & Hydrophobicity (L/g) & $\begin{array}{c}\text { Crystallinity } \\
\text { index (\%) }\end{array}$ \\
\hline Raw poplar & 54.0 & 35.8 & 10.2 & 0.68 & $3.7 \pm 0.2$ & 0.37 & 47.1 \\
10 min & 56.0 & 34.0 & 10.0 & 0.37 & $5.7 \pm 0.0$ & 0.54 & 48.9 \\
30 min & 53.8 & 37.9 & 8.3 & 0.40 & $5.9 \pm 0.0$ & 0.49 & 55.2 \\
50 min & 49.4 & 44.5 & 6.1 & 0.41 & $5.7 \pm 0.2$ & 0.31 & 56.7 \\
\hline
\end{tabular}

C1 corresponds to class of carbon that corresponds to carbon atoms bonded to carbon or hydrogen (C-C)

$\mathrm{C} 2$ corresponds to class of carbon atoms bonded to single non-carbonyl oxygen ( $\mathrm{C}-\mathrm{O}$ )

$\mathrm{C} 3$ corresponds to class of carbon atoms bonded to a carbonyl or two non-carbonyls ( $\mathrm{C}=\mathrm{O}$ or $\mathrm{O}-\mathrm{C}-\mathrm{O})$

AC-pretreated poplar $\left(5 \% \mathrm{AC}, 170{ }^{\circ} \mathrm{C}, 30 \mathrm{~min}\right)$ at $120{ }^{\circ} \mathrm{C}$ for $1 \mathrm{~h}$ with a solid loading of $10 \%(\mathrm{w} / \mathrm{v})$. After sodium hydroxide pretreatment, the glucose yield of poplar by cellulases increased from 20.0 to $35.2 \%$, indicating the increase in hydrolysis yield by alkali pretreatment. A similar phenomenon has also been observed in the hydrolysis of deacylated corncob and wood [14, 31, 34, 35]. In this work, such a low glucose yield (35.2\%) was noticed in the hydrolysis of deacylated AC-pretreated poplar, which indicated that the acetylation of poplar might be not responsible for the main reason of the low hydrolysis yield of AC-pretreated poplar. Thus, the high residual lignin contents (25.1-36.1\%) in the AC-pretreated poplar might be responsible for the relatively low hydrolysis yield $[36,37]$.

\section{HPAC pretreatment}

\section{Component analysis of HPAC-pretreated poplar}

HPAC pretreatment is gaining more interest because of its highly effective removal of lignin $[20,38,39]$. In previous report, $98.08 \%$ of acid-insoluble lignin from pine wood was removed by $100 \%$ HPAC pretreatment at $80{ }^{\circ} \mathrm{C}$ for $2 \mathrm{~h}$ [38]. After $100 \%$ HPAC pretreatment at $80{ }^{\circ} \mathrm{C}$ for $3 \mathrm{~h}$, about $90.3 \%$ lignin was removed and $86.0 \%$ enzymatic hydrolysis yield was obtained from Jerusalem artichoke [39]. It has been reported that $90.4 \%$ lignin removal and $84.0 \%$ glucose yield were observed from yellow poplar by HPAC pretreatment at $120{ }^{\circ} \mathrm{C}$ for $5 \mathrm{~min}$ [20]. In this work, after AC pretreatment, the poplar contained high lignin content $(>25 \%)$ and HPAC pretreatment was used for delignification of AC-pretreated poplar. With $40 \%, 60 \%, 80 \%$, and $100 \%$ HPAC pretreatment of AC-pretreated poplar at $60{ }^{\circ} \mathrm{C}$, the lignin content decreased from $33.4 \%$ to $22.4 \%, 15.3 \%, 4.3 \%$, and $1.2 \%$, respectively (Table 4). Pretreatment with $100 \%$ HPAC at $60{ }^{\circ} \mathrm{C}$ retained $90.9 \%$ glucan and removed 98.0\% lignin and $23.5 \%$ xylan, indicating that HPAC pretreatment showed a powerful delignification capability. As the temperature increased from 40 to $80{ }^{\circ} \mathrm{C}$, very high lignin removal (82.6-99.6\%) was observed and the contents of glucan and xylan increased due to the removal of lignin by $100 \%$ HPAC pretreatment. Meanwhile, 2.5-13.0\% glucan were lost as the HPAC pretreatment temperature increased from 40 to $80{ }^{\circ} \mathrm{C}$ (Table 4). The lowest lignin content $(0.2 \%)$ in poplar was achieved with $100 \%$ HPAC at $80{ }^{\circ} \mathrm{C}$ for $2 \mathrm{~h}$, which resulted in the highest glucan removal $(13.0 \%)$. Our results indicated that HPAC pretreatment was highly effective for removing lignin from 
poplar, which was in good agreement with the results obtained from wood [38].

\section{Characterization of HPAC-pretreated poplar}

After HPAC pretreatment (80\% HPAC, $\left.60{ }^{\circ} \mathrm{C}, 2 \mathrm{~h}\right)$, the $\mathrm{CI}$ value of the $\mathrm{AC}$-pretreated poplar $\left(5 \% \mathrm{AC}, 170{ }^{\circ} \mathrm{C}\right.$, $30 \mathrm{~min}$ ) increased from 55.2 to $64.2 \%$. The HPAC pretreatments resulted in the increase in CI possibly because of the removal of lignin fractions (Tables 4, 5) [22]. Following the HPAC pretreatment, the FTIR absorption bands at $1300-1600 \mathrm{~cm}^{-1}$ related to lignin decreased (Additional file 1: Fig. S2). In addition, several absorption bands associated with glucan increased compared with those in the raw poplar spectrum. Specifically, the $\mathrm{O}-\mathrm{H}$ stretch at $3330 \mathrm{~cm}^{-1}$ and the $\mathrm{C}-\mathrm{H}$ stretch at $2900 \mathrm{~cm}^{-1}$ associated with glucan were stronger after the two-step pretreatment [20]. The results here indicated that HPAC pretreatment removed both xylan and lignin leaving a glucan-rich poplar (Table 5).

It has been determined that in XPS analysis, the O/C ratios of different lignocellulose components decrease in the order of glucan $>$ hemicellulose $>$ lignin $[21,40]$. After the HPAC pretreatment, the $\mathrm{O} / \mathrm{C}$ ratio increased while the $\mathrm{C} 1$ peak intensity reduced $(57.1-51.0 \%)$ as lignin was removed (Table 5). The $\mathrm{O} / \mathrm{C}$ ratio $(0.40)$ and $\mathrm{C} 1$ peak intensity (53.8\%) of AC-pretreated poplar were very close to those of the HPAC-pretreated poplar. In addition, it was important to note that the content of acetyl group in the poplar increased when HPAC pretreatment became more severe (Table 5) possibly due to the formation of acetylated glucan and xylan during the pretreatment [33]. The acetylated glucan and xylan may change the $\mathrm{O} / \mathrm{C}$ ratio of the substrates. Thus, the $\mathrm{O} / \mathrm{C}$ ratio could not be used to evaluate the surface lignin content in HPACpretreated poplar. In addition, the hydrophobic acetate on the glucan surface could block the adsorption of cellulases [31].

The hydrophobicity of HPAC-pretreated poplar was lower than that of AC-pretreated poplar, and more severe HPAC pretreatment conditions reduced the hydrophobicity of the material (Table 5 and Additional file 1: Fig. S4). The main cause of this phenomenon was that the removal of lignin increased the relative contents of glucan in the remaining poplar. It has been reported that lignin is more hydrophobic than glucan, as hydrophobicity decrease as the $\mathrm{O} / \mathrm{C}$ ratio increases [24]. Obviously, the removal of xylan and lignin had a pronounced effect on the hydrophobicity of the poplar and might affect hydrolysis yield of the pretreated poplar (Fig. 2).

Compared with the AC-pretreated material, the poplar after HPAC pretreatments showed more serious surface damage in the SEM photo (Additional file 1: Fig. S5). In addition, the lignin drops formerly seen on the AC-pretreated poplar disappeared after the HPAC treatment. Similar to pseudo-lignin, the re-deposited lignin droplets on the biomass surface were observed to have detrimental impacts on the enzymatic hydrolysis [27] and the removal of lignin droplets by HPAC might be helpful for enzymatic hydrolysis of AC-pretreated poplar.

\section{Enzymatic hydrolysis of HPAC-pretreated poplar}

After $40-100 \%$ HPAC pretreatment of the AC-pretreated poplar at $60{ }^{\circ} \mathrm{C}$, the glucose yield enhanced from $20.0 \%$ to $41.7-79.2 \%$ (Fig. $2 \mathrm{a}$ ), which could be due to the removal of lignin by HPAC and the increase in cellulases
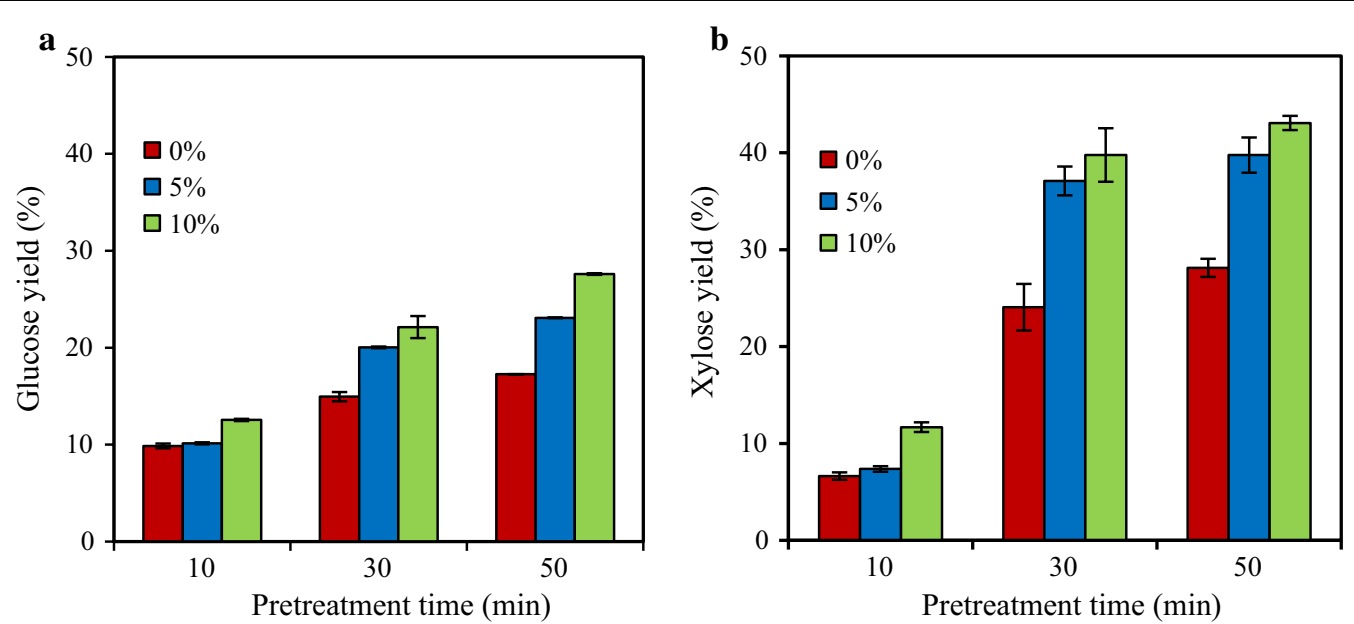

Fig. 1 Enzymatic hydrolysis of AC pretreated poplar by cellulases. Glucose (a) and xylose (b) yield from AC (0-10\% for 10-50 min) pretreated poplar by cellulases $\mathrm{CTec} 2(28.6 \mathrm{mg} / \mathrm{g} \mathrm{DM})$ at $50^{\circ} \mathrm{C}$ and $\mathrm{pH} 5.0$ for $48 \mathrm{~h}$ 
Table 4 Chemical compositions of HPAC-pretreated poplar, expressed as percentage of DM

\begin{tabular}{|c|c|c|c|c|c|c|c|c|c|c|}
\hline \multirow{2}{*}{$\begin{array}{l}\text { HPAC } \\
\text { concentration }\end{array}$} & \multirow{2}{*}{$\begin{array}{l}\text { Treatment } \\
\text { temperature }\left({ }^{\circ} \mathrm{C}\right)\end{array}$} & \multirow{2}{*}{$\begin{array}{l}\text { Severity } \\
\text { factor }\end{array}$} & \multirow{2}{*}{$\begin{array}{l}\text { Glucan } \\
\text { (\%) }\end{array}$} & \multirow{2}{*}{$\begin{array}{l}\text { Xylan } \\
(\%)\end{array}$} & \multirow{2}{*}{$\begin{array}{l}\text { Acid insoluble } \\
\text { lignin (\%) }\end{array}$} & \multirow{2}{*}{$\begin{array}{l}\text { Acid soluble } \\
\text { lignin (\%) }\end{array}$} & \multirow{2}{*}{$\begin{array}{l}\text { Solids } \\
\text { recovery (\%) }\end{array}$} & \multicolumn{3}{|c|}{ Removal } \\
\hline & & & & & & & & $\begin{array}{l}\text { Glucan } \\
(\%)\end{array}$ & $\begin{array}{l}\text { Xylan } \\
(\%)\end{array}$ & $\begin{array}{l}\text { Lignin } \\
(\%)\end{array}$ \\
\hline $\begin{array}{l}\text { AC-pretreated } \\
\text { poplar }\end{array}$ & & - & $54.9 \pm 0.4$ & $6.7 \pm 0.5$ & $33.4 \pm 0.5$ & $2.2 \pm 0.3$ & - & - & - & - \\
\hline $40 \%$ & 60 & 0.9 & $67.1 \pm 1.4$ & $8.4 \pm 0.1$ & $22.4 \pm 0.2$ & $0.4 \pm 0.0$ & 79.2 & 1.2 & 0.2 & 49.2 \\
\hline $60 \%$ & 60 & 0.9 & $76.8 \pm 0.2$ & $9.6 \pm 0.1$ & $15.3 \pm 0.1$ & $0.3 \pm 0.0$ & 68.6 & 4.1 & 1.5 & 70.0 \\
\hline $80 \%$ & 60 & 0.9 & $87.8 \pm 0.2$ & $9.2 \pm 0.4$ & $4.3 \pm 0.1$ & $0.1 \pm 0.0$ & 59.0 & 5.6 & 18.9 & 92.7 \\
\hline $100 \%$ & 40 & 0.3 & $79.9 \pm 0.5$ & $9.1 \pm 0.3$ & $9.0 \pm 0.1$ & $0.2 \pm 0.0$ & 67.0 & 2.5 & 8.4 & 82.6 \\
\hline $100 \%$ & 60 & 0.9 & $89.9 \pm 0.1$ & $9.2 \pm 0.3$ & $1.2 \pm 0.0$ & $0.1 \pm 0.0$ & 55.5 & 9.1 & 23.5 & 98.0 \\
\hline $100 \%$ & 80 & 1.5 & $89.9 \pm 0.6$ & $9.6 \pm 0.2$ & $0.2 \pm 0.0$ & $0.1 \pm 0.0$ & 53.1 & 13.0 & 24.0 & 99.6 \\
\hline
\end{tabular}

The calculation of the removal of glucan, xylan and lignin in HPAC-pretreated poplar is based on the AC-pretreated poplar

accessibility to cellulose [38]. When the pretreatment temperature increased from 40 to $80{ }^{\circ} \mathrm{C}$, the glucose yield of $100 \%$ HPAC pretreated poplar increased from 46.3 to $76.5 \%$. Meanwhile, $52.0-98.9 \%$ xylose yields were obtained from the HPAC-pretreated poplar (Fig. 2b). Such improved saccharification of HPAC-pretreated poplar could be attributed to the relatively high lignin removal (49.2\% to $99.6 \%)$ during the pretreatment process (Table 4).

The observed $67.2 \%$ glucose and $72.4 \%$ xylose yields were unexpectedly low in light of the high degree of delignification $(92.7 \%)$ which was achieved by $80 \%$ HPAC pretreatment at $60{ }^{\circ} \mathrm{C}$ for $2 \mathrm{~h}$ (Fig. 2a, Table 4). Only $76.5 \%$ glucose and $95.6 \%$ xylose yields were obtained from poplar with $99.6 \%$ lignin removal by HPAC pretreatment (100\% HPAC, $80{ }^{\circ} \mathrm{C}$ for 2 h) (Fig. 2). A similar phenomenon has also been reported that the use of HPAC-pretreated poplar led to an unexpectedly enzymatic conversion (less than $80 \%$ ) at a very low lignin content of $2.0 \%$ [41]. This phenomenon might due to the grafting of hydrophobic acetate on the cellulose surface blocked the adsorption of cellulases, thereby reducing the hydrolysis yield [31]. In order to explore the effect of acetyl content in HPAC-pretreated poplar on enzymatic hydrolysis, $0.1 \%(\mathrm{w} / \mathrm{v})$ sodium hydroxide was used to treat HPAC-pretreated poplar $\left(80 \% \mathrm{HPAC}, 60{ }^{\circ} \mathrm{C}, 2 \mathrm{~h}\right)$ at $50{ }^{\circ} \mathrm{C}$ for $1 \mathrm{~h}$ with a solid loading of $10 \%(\mathrm{w} / \mathrm{v})$ [35]. After sodium hydroxide treatment, the glucose yield of poplar increased from 67.2 to $74.4 \%$. The data indicated that the acetylation might be one of reason to hinder the enzymatic hydrolysis of HPAC-pretreated poplar.

Interestingly, $2.7 \mathrm{mg} / \mathrm{mL}$ cellobiose was produced in the enzymatic hydrolysis of the HPAC-pretreated $(80 \%$ HPAC, $60{ }^{\circ} \mathrm{C}, 2 \mathrm{~h}$ ) poplar, which can strongly inhibit the action of cellobiohydrolase I and reduce enzymatic hydrolysis yield [42]. Supplementation of CTec2 cellulases with $11.1 \mathrm{mg}$ protein of $\beta$-glucosidase per g DM improved the glucose and xylose yields from $67.2 \%$ and $72.4 \%$ to $94.0 \%$ and $97.0 \%$, respectively (Fig. 3a).

Meanwhile, $0.05-0.24 \mathrm{mg} / \mathrm{mL}$ XOS (DP 2-6) were found in the enzymatic hydrolyte of HPAC-pretreated poplar. The inhibition of XOS to cellulases could also affect the hydrolysis yield of the HPAC-pretreated poplar [43]. Similar phenomenon has been reported that adding extra $\beta$-glucosidase with CTec 2 improved the glucose and xylose yields of glycerol treated Miscanthus straw from $12.5 \%$ and $4.2 \%$ to $88.8 \%$ and $68.5 \%$, respectively [44]. In this work, relatively high content of cellobiose in the hydrolysate of HPAC-pretreated poplar could inhibit the hydrolytic capacity of xylanase in CTec2 and decreased the xylose yield [45].

It has been reported that the use of surfactants in enzymatic hydrolysis can reduce the non-productive binding between lignin and cellulases and improve the enzymatic hydrolysis yield [46, 47]. 97.4\% Glucose and 98.6\% xylose yields were obtained from the HPAC-pretreated poplar after supplementation of $1 \mathrm{mg} / \mathrm{mL}$ Tween 80 with $28.6 \mathrm{mg}$ protein of cellulases/g DM (Fig. 3b, c). After addition of Tween 80, the HPAC-pretreated poplar presented a remarkable hydrolysis yields of glucose $(86.6 \%)$ and xylose $(89.0 \%)$ with a cellulases loading of $7.2 \mathrm{mg} / \mathrm{g}$ DM (Fig. 3d), which could be explained by that Tween 80 increased the activity or stability of $\beta$-glucosidase and consequently alleviated the accumulation of cellobiose. Additionally, very high glucose (93.8\%) and xylose (94.6\%) yields also were obtained $14.3 \mathrm{mg}$ protein of cellulases/g DM. Thus, employing Tween 80 instead of $\beta$-glucosidase was a viable mean to improve the hydrolysis yield. In this work, compared with previous reports on poplar $86.6 \%$ glucose yield with a cellulases loading $(7.2 \mathrm{mg}$ protein/g DM) or $93.8 \%$ glucose yield with $7.2 \mathrm{mg}$ protein of cellulases/g DM and $1 \mathrm{mg} / \mathrm{mL}$ Tween 80 achieved satisfactory results $[6,7,9,15]$. It has been reported that acetyl groups might inhibit the enzymes by 
interfering with the productive binding between cellulose and the catalytic domain of cellulases [31]. However, Tween 80 can change the ultrastructure of the substrate, making the cellulose more available to enzymatic attack and increase enzyme stability by reducing thermal denaturation or denaturation by shear forces [46]. Hence, this might be the reason that the Tween 80 increased enzymatic hydrolysis yield of the HPAC-pretreated poplar.

\section{Comparison of different pretreatment methods of poplar}

This work proposed a two-step pretreatment for the efficient production of XOS and fermented sugars from poplar and $6.9 \mathrm{~g}$ XOS, $40.3 \mathrm{~g}$ glucose and $8.9 \mathrm{~g}$ xylose could be produced from $100 \mathrm{~g}$ of poplar (Fig. 4). The AC and HPAC pretreated poplar presented remarkable hydrolysis yields of $86.6 \%$ glucose and $89.0 \%$ xylose at a cellulases loading of $7.2 \mathrm{mg} / \mathrm{g} \mathrm{DM}$ and very high glucose (93.8\%) and xylose (94.6\%) yields were obtained with $14.3 \mathrm{mg}$ protein of cellulases/g DM. The AC pretreatment and HPAC pretreatment were milder and more efficient than those associated with various typical poplar pretreatments (Table 6). Single step pretreatments such as steam explosion and those using alkaline peroxide or ionic liquids all require high temperatures and long treatment times and exhibit low enzymatic hydrolysis rates and poor conversion of certain components [6-8, 48, 49]. For example, only $60 \%$ enzymatic hydrolysis yield was obtained from poplar by a high temperature $\left(210^{\circ} \mathrm{C}\right)$ steam explosion pretreatment [7]. In the sulfuric acid and steam explosion pretreatments, the first step poplar pretreatment condition was $0.7 \% \mathrm{H}_{2} \mathrm{SO}_{4}$ at room temperature overnight and the second step pretreatment condition was steam explosion at $190{ }^{\circ} \mathrm{C}$ for $10 \mathrm{~min}$ and finally only $70 \%$ glucose yield was obtained by $72 \mathrm{~h}$ enzymatic hydrolysis with loading $32 \mathrm{mg}$ cellulases/g DM [9]. Additionally, twostep poplar pretreatments such as sodium hydroxide and sodium sulfate, white-rot and sodium hydroxide, sulfuric acid and steam explosion, sulfur dioxide steam explosion and ethanol can improve poplar hydrolysis yield, but the associated conditions are still very severe $[5,9,10]$. In this work, xylan in poplar was efficiently used for XOS production and glucan was almost completely hydrolysis. After $\mathrm{AC}$ pretreatment, the $\mathrm{AC}$ concentration in pretreatment liquor $\left(5.2 \mathrm{mg} / \mathrm{mL} \mathrm{AC}, 170{ }^{\circ} \mathrm{C}, 30 \mathrm{~min}\right)$ was $4.7 \mathrm{mg} / \mathrm{mL}$ (Additional file 1: Table S1). AC in the pretreatment liquor can be recycled by liquid-liquid extraction [50]. During the HPAC pretreatment, the AC was consumed and peroxyacetic acid was formed. Pressure shift distillation coupled with a separation process was capable to separate AC and peroxyacetic acid in HPAC pretreatment liquor $[51,52]$. The two-step pretreatment of AC and HPAC provided a preferable feature to prepare $\mathrm{XOS}$ and monosaccharides from poplar with relatively mild conditions, showing great potential application in industrial production of XOS, biofuels, and biochemicals from biomass.

\section{Conclusions}

The AC pretreatment of poplar solubilized the most xylan in poplar and gave rise to a $55.8 \%$ XOS yield. The HPAC pretreatment presented 49.2-99.6\% lignin removal of AC-pretreated poplar and improved the glucose yield from $20.0 \%$ to above $90 \%$ with a dosage of $14.3 \mathrm{mg}$ protein of cellulases/g DM and $11.1 \mathrm{mg}$ protein of $\beta$-glucosidase/g DM or $1 \mathrm{mg} / \mathrm{mL}$ Tween 80 . The two-step pretreatment offered an approach to effectively converting $100 \mathrm{~g}$ poplar to $6.9 \mathrm{~g}$ XOS and $49.2 \mathrm{~g}$ monosaccharides. The AC and HPAC two-step pretreatment of poplar for producing XOS and fermentable sugars could facilitate means to develop an economically viable biorefinery process.

\section{Methods}

\section{Materials}

Poplar used in this work was kindly supplied by Prof. Yong $\mathrm{Xu}$ from Nanjing Forestry University. The material was air dried for 3 days, followed by pulverization to obtain a powder with an 80 mesh particle size $(\leq 0.178 \mathrm{~mm})$, having a

Table 5 XPS, acetyl, hydrophobicity, and crystallinity index (\%) analysis of HPAC-pretreated poplar

\begin{tabular}{|c|c|c|c|c|c|c|c|c|}
\hline Treatment temperature & $\begin{array}{l}\text { HPAC } \\
\text { concentration } \\
(\%)\end{array}$ & C1 (\%) & C2 (\%) & C3 (\%) & $\mathrm{O} / \mathrm{C}$ & Acetyl (\%) & $\begin{array}{l}\text { Hydrophobicity } \\
\text { (L/g) }\end{array}$ & $\begin{array}{l}\text { Crystallinity } \\
\text { index }(\%)\end{array}$ \\
\hline AC-pretreated poplar & & 53.8 & 38.0 & 8.3 & 0.40 & $5.9 \pm 0.0$ & 0.49 & 55.2 \\
\hline $60^{\circ} \mathrm{C}$ & 40 & 57.1 & 29.1 & 13.7 & 0.40 & $7.6 \pm 0.1$ & 0.27 & 57.7 \\
\hline $60^{\circ} \mathrm{C}$ & 60 & 53.6 & 33.1 & 13.2 & 0.43 & $8.0 \pm 0.0$ & 0.14 & 63.0 \\
\hline $60^{\circ} \mathrm{C}$ & 80 & 52.9 & 33.7 & 13.4 & 0.46 & $8.1 \pm 0.0$ & 0.07 & 64.2 \\
\hline $40^{\circ} \mathrm{C}$ & 100 & 56.1 & 32.5 & 11.4 & 0.44 & $8.1 \pm 0.2$ & 0.21 & 60.1 \\
\hline $60^{\circ} \mathrm{C}$ & 100 & 52.9 & 36.2 & 11.0 & 0.46 & $8.0 \pm 0.2$ & 0.06 & 64.9 \\
\hline $80^{\circ} \mathrm{C}$ & 100 & 51.0 & 37.5 & 11.6 & 0.49 & $9.7 \pm 0.1$ & 0.06 & 68.5 \\
\hline
\end{tabular}



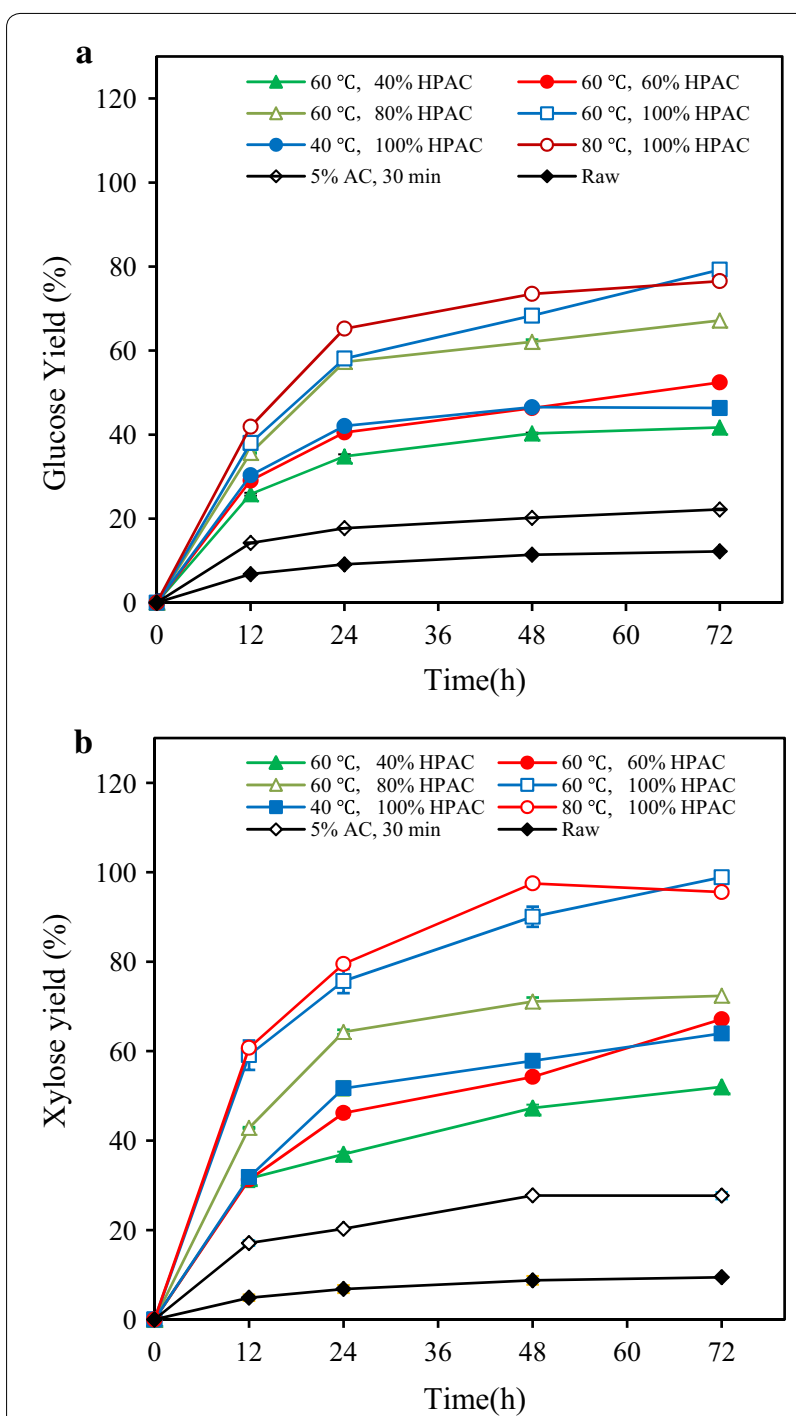

Fig. 2 Glucose (a) and xylose (b) yields from 2\% HPAC-pretreated poplar by CTec2 $(28.6 \mathrm{mg} / \mathrm{g} \mathrm{DM})$ at $50^{\circ} \mathrm{C}$ and $\mathrm{pH} 5.0$ for $72 \mathrm{~h}$. The HPAC pretreatment of poplar was based on the poplar pretreated with $5 \% \mathrm{AC}$ at $170^{\circ} \mathrm{C}$ for $30 \mathrm{~min}$

moisture content of $9.40 \%$. The contents of glucan, xylan, acid insoluble lignin and acid soluble lignin in the raw poplar were $43.38 \%, 17.36 \%, 24.43 \%$, and $3.50 \%$, respectively, determined using a method published by the National Renewable Energy Laboratory [53].

Cellic CTec2 (Novozymes A/S, Bagsværd, Denmark) had an activity of 123.0 filter paper units (FPU)/ $\mathrm{mL}$ (176.2 $\mathrm{mg}$ protein $/ \mathrm{mL}$ ) determined according to the International Union of Pure and Applied Chemistry standard assay [54]. The Novozyme 188 ( $\beta$-glucosidase) was determined to be $8451 \mathrm{nkat} / \mathrm{mL}$ (187.9 mg protein/ $\mathrm{mL}$ ) as described previously [55]. The enzyme protein was quantified by the Lowry method using bovine serum albumin (Sigma-Aldrich, St. Louis, MO, USA) as the standard [56]. Xylobiose, xylotriose, xylotetraose, xylopentaose, and xylohexaose were purchased from Megazyme (Wicklow, Ireland).

\section{AC pretreatment}

The AC pretreatment was performed in a sealed, Teflonlined stainless steel autoclave (HT-100H-316L, Anhui Kemi Machinery Technology Co., Ltd., Anhui, China) heated in a Constant Temperature Oil Bath (HH-SB, Jinhua Wenhua Equipment and Instrument Co., Ltd., Zhejiang, China). The AC pretreatment conditions were referred to a previous report [15]. The system was heated about $30 \mathrm{~min}$ from 25 to $170{ }^{\circ} \mathrm{C}\left(5^{\circ} \mathrm{C} / \mathrm{min}\right)$. AC concentrations of $0 \%, 5 \%(5.2 \mathrm{mg} / \mathrm{mL})$, or $10 \%(\mathrm{v} / \mathrm{v})(10.5 \mathrm{mg} /$ $\mathrm{mL}$ ) were used to treat poplar samples with a solid loading of $10 \%(\mathrm{w} / \mathrm{v})$. The process was performed at $170{ }^{\circ} \mathrm{C}$ for 10,30 or $50 \mathrm{~min}$. Each experiment was carried out in triplicate. Following the reaction, the sealed tank was taken out from oil bath and immediately cooled down to room temperature with tap water in $30 \mathrm{~min}$. The pretreatment liquor was separated from the slurry through vacuum filtration. Part of pretreatment liquor was used to determine the XOS concentration. The solid was recovered by filtration and washed repeatedly with distilled water until the wash water had a neutral $\mathrm{pH}$, then stored at $-20{ }^{\circ} \mathrm{C}$ for chemical composition analysis and enzymatic hydrolysis.

\section{HPAC pretreatment}

A sample of poplar pretreated by $5 \% \mathrm{AC}$ at $170{ }^{\circ} \mathrm{C}$ for 30 min was employed for the subsequent HPAC pretreatment. The HPAC solution was prepared by mixing hydrogen peroxide $(30 \%, \mathrm{w} / \mathrm{w})$ and acetic acid $(99 \%, \mathrm{w} / \mathrm{w})$ at a ratio of $1: 1(\mathrm{v} / \mathrm{v})$ [38]. To investigate the effects of temperature on HPAC pretreatment, AC-pretreated poplar were pretreated with $100 \%(\mathrm{v} / \mathrm{v}) \mathrm{HPAC}$ at temperatures of $40{ }^{\circ} \mathrm{C}, 60^{\circ} \mathrm{C}$, and $80^{\circ} \mathrm{C}$. The effect of HPAC concentration $(40-100 \%, v / v)$ on pretreatment was investigated at $60{ }^{\circ} \mathrm{C}$. All pretreatments were preformed for $2 \mathrm{~h}$ at a solid to liquid ratio of 1:10 (w/v) with $100 \mathrm{mM} \mathrm{H}_{2} \mathrm{SO}_{4}$ as a catalyst. The solid residues were separated by filtration and washed extensively with distilled water until the wash water had a neutral $\mathrm{pH}$, then stored at $-20^{\circ} \mathrm{C}$ for chemical composition analysis and enzymatic hydrolysis.

\section{Enzymatic hydrolysis}

Hydrolysis of the raw and treated poplar was performed in test tubes (601051-1, Biosharp, Hefei, China) with a $3 \mathrm{~mL}$ working volume in a $50 \mathrm{mM}$ sodium citrate buffer (pH 5.0) at $50{ }^{\circ} \mathrm{C}$ and $200 \mathrm{rpm}$ [53]. $\mathrm{NaN}_{3}(0.02 \% \mathrm{w} / \mathrm{v})$ 

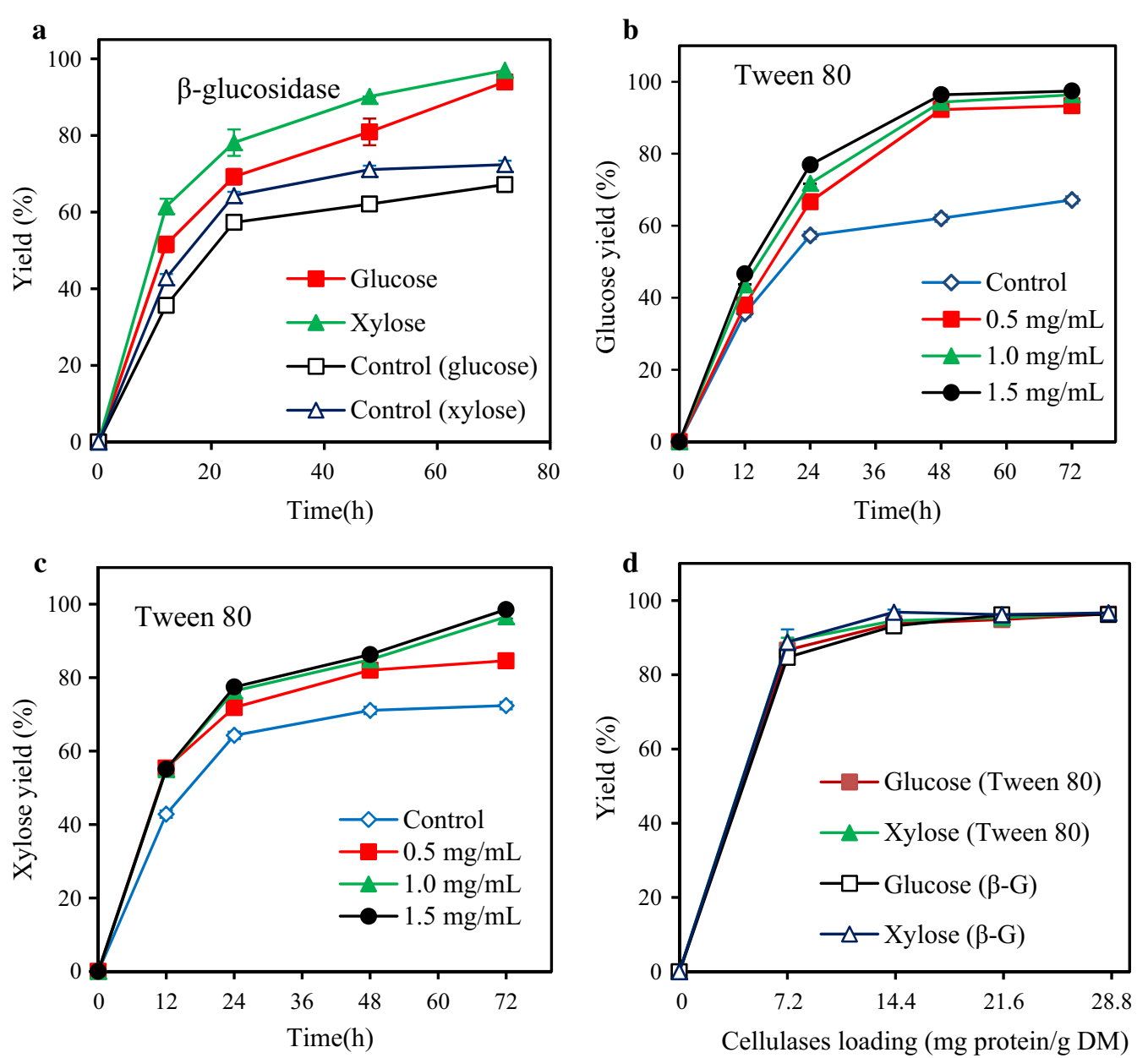

Fig. 3 Effects of Tween 80 and $\beta$-glucosidase on the hydrolysis of $2 \% \mathrm{HPAC}$-pretreated poplar $\left(80 \% \mathrm{HPAC}, 60^{\circ} \mathrm{C}\right) \mathrm{CTec2}(28.6 \mathrm{mg} / \mathrm{g} \mathrm{DM})$ at $50^{\circ} \mathrm{C}$ and $\mathrm{pH} 5.0$ for $72 \mathrm{~h}$. a Effect of $\beta$-glucosidase $(11.1 \mathrm{mg} / \mathrm{g} \mathrm{DM})$ on glucose and xylose yields. $\mathbf{b}$ Effect of Tween $80(0.5-1.5 \mathrm{mg} / \mathrm{mL})$ on glucose yield. c Effect of Tween $80(0.5-1.5 \mathrm{mg} / \mathrm{mL})$ on xylose yield. d Effect of Tween $80(1.0 \mathrm{mg} / \mathrm{mL})$ and $\beta$-glucosidase $(11.1 \mathrm{mg} / \mathrm{g}$ DM) on the hydrolysis with different CTec2 loading

was added to the hydrolysis broth to prevent bacterial growth. The AC-pretreated poplar loading in each reaction mixture was $2 \%(\mathrm{w} / \mathrm{v})$, with a cellulases loading of 14.3, 28.6, 43.0, 57.3, 71.3, $85.8 \mathrm{mg}$ protein $(10,20,30,40$, 50, $60 \mathrm{FPU}) / \mathrm{g}$ DM. The cellulases loading in hydrolysis of HPAC-pretreated poplar was 7.2, 14.3, 21.5, $28.6 \mathrm{mg}$ protein $(5,10,15,20 \mathrm{FPU}) / \mathrm{g} \mathrm{DM}$. The $\beta$-glucosidase loading was 500 nakt (11.1 mg protein)/g DM for hydrolysis of HPAC-pretreated poplar. The concentration of Tween 80 in hydrolysate was $0.5-1.5 \mathrm{mg} / \mathrm{mL}$. Two tubes of replicate test were withdrawn at intervals ranging from 12 to $72 \mathrm{~h}$ and boiled for $10 \mathrm{~min}$ to stop the enzymatic hydrolysis. Enzymatic hydrolysate was boiled for $10 \mathrm{~min}$ to stop the enzymatic hydrolysis. After cooling, the samples were separated by centrifugation $(10,000 \times g, 10 \mathrm{~min})$ and the cellobiose, XOS, glucose, and xylose in the supernatants were analyzed. Two replicate tests were performed for all hydrolysis experiments and average values are presented.

\section{Characterization of solid residues}

The crystallinity index $(\mathrm{CI})$ of each raw and treated poplar specimen was determined by XRD using a Rigaku D/ max-3 C instrument (Rigaku Corporation, Japan) [19]. The $\mathrm{CI}$ was determined using the equation:

$$
\mathrm{CI} \%=\frac{I_{002}-I_{\mathrm{am}}}{I_{002}} \times 100 \%
$$

where $I_{002}$ is the maximum intensity of the diffraction at approximately $22.5^{\circ}$ that corresponds to crystalline regions and $I_{\text {am }}$ is the minimum intensity of the peak at approximately $18.0^{\circ}$ that corresponds to amorphous regions. 


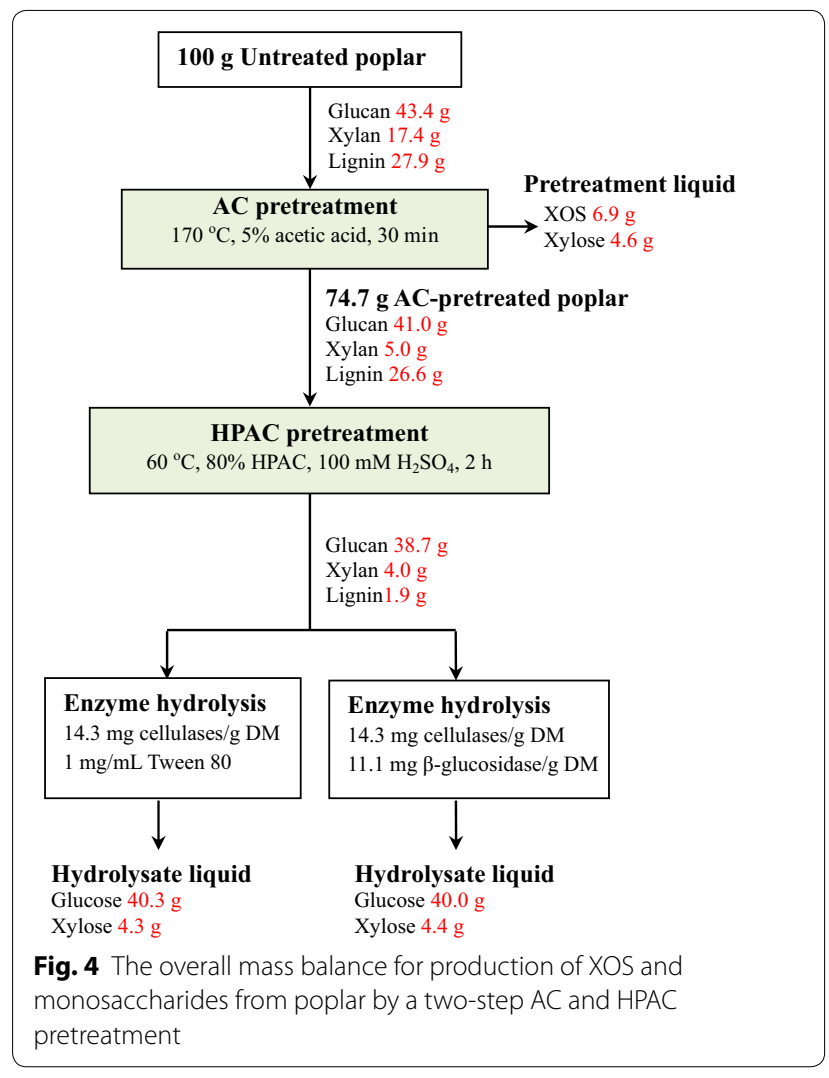

Chemical functional groups were characterized using a Nicolet iS10 FTIR spectrophotometer (Thermo Fisher, USA), acquiring spectra over the range of $4000-400 \mathrm{~cm}^{-1}$ and adding 32 scans to generate each spectrum. The background spectrum of the diamond window without a sample was subtracted from each sample spectrum.

XPS analyses were performed based on the method reported by Kumar and Montplaisi to determine the atomic compositions and chemical environments of the poplar sample surfaces [24,57]. The hydrophobicities of the poplar samples were determined via the method previously described $[58,59]$.

The surface morphologies of the raw and pretreated poplar specimens were observed by SEM (JSM 6360LV, Jeol, Japan) with an acceleration voltage of $10 \mathrm{kV}$. The samples were coated with gold to make them conductive before imaging and images were acquired at 1000, 2000 and $5000 \times$ magnification.

\section{Analytical methods}

The acetyl contents of poplar solids were determined as per NREL LAP002 using glacial acetic acid as a calibration standard [53].

The calculation of XOS (DP 2-6) yields was based on the removed xylan in the pretreatment liquor. Total

Table 6 The enzyme hydrolysis of pretreated poplar by different methods

\begin{tabular}{|c|c|c|c|c|}
\hline Raw material & Pretreatment method and conditions & Enzyme hydrolysis condition & Glucose yield (\%) & References \\
\hline \multirow[t]{3}{*}{ Transgenic poplar } & {$\left[\mathrm{C}_{2} \mathrm{C}_{1} \mathrm{Im}\right][\mathrm{OAc}]$ at $160^{\circ} \mathrm{C}$ for $3 \mathrm{~h}$} & $10 \mathrm{mg}$ protein of cellulases/g DM in $72 \mathrm{~h}$ & $<35.0$ & [6] \\
\hline & {$[\mathrm{Ch}][$ Lys $]$ at $140^{\circ} \mathrm{C}$ for $1 \mathrm{~h}$} & $10 \mathrm{mg}$ protein of cellulases/g DM in $72 \mathrm{~h}$ & $<40.0$ & \\
\hline & {$[\mathrm{TBA}][\mathrm{OH}]$ at $70^{\circ} \mathrm{C}$ for $3 \mathrm{~h}$} & $10 \mathrm{mg}$ protein of cellulases/g DM in $72 \mathrm{~h}$ & $<30.0$ & \\
\hline Poplar & Steam explosion at $210^{\circ} \mathrm{C}$ for $4 \mathrm{~min}$ & $15 \mathrm{FPU}$ cellulases/g DM in $72 \mathrm{~h}$ & $<63.0$ & [7] \\
\hline Sacrau poplar & $2 \% \mathrm{NaOH}$ with $1 \% \mathrm{H}_{2} \mathrm{O}_{2}$ at $160^{\circ} \mathrm{C}$ for $2 \mathrm{~h}$ & $20 \mathrm{FPU}$ cellulases/g DM and Tween 80 in $72 \mathrm{~h}$ & 88.2 & [12] \\
\hline Poplar & $6.5 \%$ acetic acid at $172^{\circ} \mathrm{C}$ for $27 \mathrm{~min}$ & $20 \mathrm{FPU}$ cellulases/g cellulose in $108 \mathrm{~h}$ & $<51.0$ & [15] \\
\hline Poplar & $0.1 \mathrm{M} \mathrm{H}_{2} \mathrm{SO}_{4}$ at $160^{\circ} \mathrm{C}$ for $35 \mathrm{~min}$ & $\begin{array}{l}112.5 \mathrm{mg} \text { protein of cellulases }+37.5 \mathrm{mg} \text { pro- } \\
\text { tein of xylanases/g glucan + xylan in } 72 \mathrm{~h}\end{array}$ & $<60$ & [48] \\
\hline Poplar & Hot water at $180^{\circ} \mathrm{C}$ for $12 \mathrm{~min}$ & $15 \mathrm{mg}$ protein of cellulases/g glucan in $120 \mathrm{~h}$ & 60.0 & [49] \\
\hline Hybrid poplar & $\begin{array}{l}\text { First step: } 8 \% \mathrm{NaOH} \text { at } 90^{\circ} \mathrm{C} \text { for } 10 \mathrm{~h} \\
\text { Second step: } 4 \% \mathrm{Na}_{2} \mathrm{SO}_{3} \text { at } 180^{\circ} \mathrm{C} \text { for } 60 \mathrm{~min}\end{array}$ & $15 \mathrm{FPU}$ cellulases/g DM in $72 \mathrm{~h}$ & 94.5 & [5] \\
\hline Poplar & $\begin{array}{l}\text { First step: } 0.7 \% \mathrm{H}_{2} \mathrm{SO}_{4} \text { at room temperature } \\
\text { overnight } \\
\text { Second step: steam explosion at } 190^{\circ} \mathrm{C} \text { for } \\
10 \mathrm{~min}\end{array}$ & $32 \mathrm{mg}$ cellulases protein/g DM in $72 \mathrm{~h}$ & 70 & [9] \\
\hline Poplar & $\begin{array}{l}\text { First step: } \mathrm{SO}_{2} \text { steam explosion at } 170{ }^{\circ} \mathrm{C} \text { for } \\
15 \text { min } \\
\text { Second step: ethanol with } 1 \% \mathrm{H}_{2} \mathrm{SO}_{4} \text { at } 170{ }^{\circ} \mathrm{C} \\
\text { for } 60 \mathrm{~min}\end{array}$ & 5 FPU cellulases/g cellulose in $72 \mathrm{~h}$ & 85 & {$[10]$} \\
\hline Poplar & $\begin{array}{l}\text { First step: } 5 \% \mathrm{AC} 170^{\circ} \mathrm{C} \text { for } 30 \mathrm{~min} \\
\text { Second step: } 80 \% \mathrm{HPAC} \text { at } 60^{\circ} \mathrm{C} \text { for } 2 \mathrm{~h}\end{array}$ & $\begin{array}{l}7.2 \mathrm{mg} \text { protein of cellulases/g DM and Tween } \\
80 \text { in } 72 \mathrm{~h}\end{array}$ & 86.6 & This study \\
\hline Poplar & $\begin{array}{l}\text { First step: } 5 \% \mathrm{AC} 170^{\circ} \mathrm{C} \text { for } 30 \text { min } \\
\text { Second step: } 80 \% \mathrm{HPAC} \text { at } 60^{\circ} \mathrm{C} \text { for } 2 \mathrm{~h}\end{array}$ & $\begin{array}{l}14.3 \mathrm{mg} \text { protein of cellulases/g DM and Tween } \\
80 \mathrm{in} 72 \mathrm{~h}\end{array}$ & 93.8 & This study \\
\hline
\end{tabular}


oligosaccharide contents of the $\mathrm{AC}$ pretreatment liquors were determined indirectly after quantitative acid hydrolysis with $4 \% \mathrm{H}_{2} \mathrm{SO}_{4}$ at $121{ }^{\circ} \mathrm{C}$ for $1 \mathrm{~h}$, according to NREL/TP-510-42623. XOS (DP 2-6) was analyzed using high performance anion exchange chromatography coupled with pulsed amperometric detection (Dionex ICS5000). The analysis employed $0.1 \mathrm{M} \mathrm{NaOH}$ and $0.5 \mathrm{M}$ $\mathrm{NaOAc}$ containing $0.1 \mathrm{M} \mathrm{NaOH}$ as the mobile phases, at a flow rate of $0.3 \mathrm{~mL} / \mathrm{min}$ in conjunction with a CarboPac PA200 anion exchange column [60].

Acetic acid, cellobiose, and monosaccharides were analyzed by high-performance liquid chromatography (Agilent 1260), using an Aminex Bio-Rad HPX-87H column and a refractive index detector together with $5 \mathrm{mM}$ $\mathrm{H}_{2} \mathrm{SO}_{4}$ as the mobile phase at a flow rate of $0.5 \mathrm{~mL} / \mathrm{min}$. All samples were diluted with Milli-Q water prior to analysis. Two replicate assays were performed for each sample, and average values are presented.

\section{Calculations}

The pretreatment severity factor was used to monitor and compare the pretreatment severity $[24,61]$.

$$
\text { Severity factor }=\log \left[t * \exp \left(\frac{T_{\mathrm{i}}-T}{14.75}\right)\right]
$$

where $t$ refers to pretreatment time ( $\mathrm{min}), T_{\mathrm{i}}$ is the reaction temperature $\left({ }^{\circ} \mathrm{C}\right)$, and $T$ is the reference temperature of $100{ }^{\circ} \mathrm{C}$.

The percent recovery and percent removal of each component were calculated by the following formula [62]:

$$
\text { Soild recovery }(\%)=\frac{W_{\text {after pretreatment }}}{W_{\text {before pretreatment }}} \times 100
$$

where $W_{\text {before pretreatment }}$ and $W_{\text {after pretreatment }}$ were the weight of poplar before and after pretreatment.

$$
\operatorname{Removal}(\%)=1-\frac{W_{\text {component after pretreatment }}}{W_{\text {component before pretreatment }}} \times 100
$$

where $W_{\text {component before pretreatment }}$ and $W_{\text {component after pretreat- }}$ ment were the weight of the components (cellulose, xylan and, lignin) in poplar before and after pretreatment (g).

The xylose and XOS (DP 2 to 6) yields from AC pretreatment liquor were calculated based on the following equations $[16,63]$ :

$$
\begin{aligned}
& \text { Xylose yield }_{\mathrm{AC} \text { pretreatment liquor }}(\%) \\
& =\frac{\text { Xylose in } \mathrm{AC} \text { pretreatment liquor }(\mathrm{g}) \times 0.88}{\text { Removed xylan in AC pretreatment liquor }(\mathrm{g})} \times 100
\end{aligned}
$$

$$
\begin{aligned}
& \text { XOS yield AC pretreatment liquor }(\%) \\
& =\frac{\text { XOS (DP } 2-6) \text { in AC pretreatment liquor }(\mathrm{g})}{\text { Removed xylan in AC pretreatment liquor }(\mathrm{g})} \times 100
\end{aligned}
$$

The yields of glucose, xylose, cellobiose, and XOS (DP 2 to 6) were calculated based on the following equations [16]:

Glucose yield (\%)

$$
\begin{aligned}
= & \frac{\text { Glucose in enzymatic hydrolysate } \times 0.9}{\text { Theoretical amount of glucan in pretreated poplar }} \\
& \times 100
\end{aligned}
$$

Cellobiose yield (\%)

$$
\begin{aligned}
= & \frac{\text { Cellobiose in enzymatic hydrolysate } \times 0.9}{\text { Theoretical amount of glucan in pretreated poplar }} \\
& \times 100
\end{aligned}
$$

Xylose yield (\%)

$$
\begin{aligned}
= & \frac{\text { Xylose in enzymatic hydrolysate } \times 0.88}{\text { Theoretical amount of glucan in pretreated poplar }} \\
& \times 100
\end{aligned}
$$

XOS yield (\%)

$$
\begin{aligned}
= & \frac{\mathrm{XOS}(\mathrm{DP} 2-6) \text { in enzymatic hydrolysate }}{\text { Theoretical amount of xylan in pretreated poplar }} \\
& \times 100
\end{aligned}
$$

\section{Additional file}

Additional file 1: Table S1. The AC concentration and recovery of AC pretreatment liquor. Figure S1. XRD analysis of raw and two steps treated. Figure S2. FT-IR spectrum of raw and two steps pretreated poplar. Figure S3. XPS analysis of raw and two steps pretreated poplar. Figure S4. Hydrophobicity of raw and two steps pretreated poplar. Figure S5. SEM analysis of raw and two steps pretreated poplar. Figure S6. Effect of CTec2 loading on the hydrolysis of poplar $(2 \%)$ pretreated by $\mathrm{AC}\left(5 \%, 170{ }^{\circ} \mathrm{C}\right.$, $30 \mathrm{~min}$ ) for $48 \mathrm{~h}$.

\section{Abbreviations}

AC: acetic acid; HPAC: hydrogen peroxide-acetic acid; XOS: xylooligosaccharides; DM: dry mass; FT-IR: Fourier transform-infrared; SEM: scanning electron microscopy; XRD: X-ray diffraction; XPS: X-ray photoelectron spectroscopy; FPU: filter paper unit.

\section{Authors' contributions}

PW and TZ designed the project, carried out the experiments, analyzed the data, and drafted the manuscript. ZL conducted the experiment on the determination of XOS. JW reviewed it. JZ designed and coordinated the overall study and finalized the paper. All authors read and approved the final manuscript. 


\begin{abstract}
Author details
${ }^{1}$ College of Forestry, Northwest A\&F University, 3 Taicheng Road, Yangling 712100, Shaanxi, China. ${ }^{2}$ Co-Innovation Center for Efficient Processing and Utilization of Forest Products, College of Chemical Engineering, Nanjing Forestry University, Nanjing 210037, Jiangsu, China.
\end{abstract}

\section{Acknowledgements}

Not applicable.

\section{Competing interests}

The authors declare that they have no competing interests.

\section{Availability of supporting data}

All relevant data have been included in this published article and its Additional file 1.

\section{Consent for publication}

All the authors approved the manuscript.

\section{Ethics approval and consent to participate}

Not applicable.

\section{Funding}

This work was supported by the National Key R\&D Program of China (No. 2017YFD0601001) and the Natural Science Foundation of China (No. 31670598).

\section{Publisher's Note}

Springer Nature remains neutral with regard to jurisdictional claims in published maps and institutional affiliations.

Received: 29 January 2019 Accepted: 3 April 2019

Published online: 15 April 2019

\section{References}

1. Satari B, Karimi K, Kumar R. Cellulose solvent-based pretreatment for enhanced second-generation biofuel production: a review. Sustain Energy Fuels. 2019;3:11-62.

2. Wyman CE, Cai CM, Kumar R. Bioethanol from lignocellulosic biomass. In: Kaltschmitt M, editor. Energy from organic materials (Biomass): a volume in the encyclopedia of sustainability science and technology. 2nd ed. New York: Springer New York; 2019. p. 997-1022.

3. Sannigrahi P, Ragauskas AJ, Tuskan GA. Poplar as a feedstock for biofuels: a review of compositional characteristics. Biofuel Bioprod Biorefin. 2010;4(2):209-26.

4. Devappa RK, Rakshit SK, Dekker RF. Forest biorefinery: potential of poplar phytochemicals as value-added co-products. Biotechnol Adv. 2015;33(6):681-716.

5. Jiang H, Han B, Ge J. Enhancement in the enzymatic digestibility of hybrid poplar with poor residual hemicelluloses after $\mathrm{Na}_{2} \mathrm{SO}_{3}$ pretreatment. Bioresour Technol. 2015;180:338-44.

6. Kim KH, Dutta T, Ralph J, Mansfield SD, Simmons BA, Singh S. Impact of lignin polymer backbone esters on ionic liquid pretreatment of poplar. Biotechnol Biofuels. 2017;10:101.

7. Negro MJ, Manzanares P, Ballesteros I, Oliva JM, Cabañas A, Ballesteros M. Hydrothermal pretreatment conditions to enhance ethanol production from poplar biomass. Appl Biochem Biotechnol. 2003;105(1-3):87-100.

8. Zhang $L$, You T, Zhang L, Yang H, Xu F. Enhanced fermentability of poplar by combination of alkaline peroxide pretreatment and semisimultaneous saccharification and fermentation. Bioresour Technol. 2014;164:292-8

9. Tian D, Chandra RP, Lee JS, Lu C, Saddler JN. A comparison of various lignin-extraction methods to enhance the accessibility and ease of enzymatic hydrolysis of the cellulosic component of steam-pretreated poplar. Biotechnol Biofuels. 2017;10:157.

10. Panagiotopoulos IA, Chandra RP, Saddler JN. A two-stage pretreatment approach to maximise sugar yield and enhance reactive lignin recovery from poplar wood chips. Bioresour Technol. 2013;130(1):570-7.
11. Qing Q, Li H, Kumar R, Wyman CE. Xylooligosaccharides production, quantification, and characterization in context of lignocellulosic biomass pretreatment. In: Aqueous pretreatment of plant biomass for biological and chemical conversion to fuels and chemicals. 2013. p. 391-415.

12. Zhang H, Zhou X, Xu Y, Yu S. Production of xylooligosaccharides from waste xylan, obtained from viscose fiber processing, by selective hydrolysis using concentrated acetic acid. J Wood Chem Technol. 2017;37(1):1-9.

13. Boonchuay $P$, Techapun C, Leksawasdi N, Seesuriyachan $P$, Hanmoungjai $P$, Watanabe M, Takenaka S, Chaiyaso T. An integrated process for xylooligosaccharide and bioethanol production from corncob. Bioresour Technol. 2018;256:399-407.

14. Zhang H, Xu Y, Yu S. Co-production of functional xylooligosaccharides and fermentable sugars from corncob with effective acetic acid prehydrolysis. Bioresour Technol. 2017;234:343-9.

15. Huang K, Luo J, Cao R, Su Y, Xu Y. Enhanced xylooligosaccharides yields and enzymatic hydrolyzability of cellulose using acetic acid catalysis of poplar sawdust. J Wood Chem Technol. 2018;38(5):371-84.

16. Huang $C$, Jeuck $B$, Du J, Yong $Q$, Chang $H$, Jameel $H$, Phillips $R$. Novel process for the coproduction of xylo-oligosaccharides, fermentable sugars, and lignosulfonates from hardwood. Bioresour Technol. 2016;219:600-7.

17. Zhang K, Pei Z, Wang D. Organic solvent pretreatment of lignocellulosic biomass for biofuels and biochemicals: a review. Bioresour Technol. 2016;199:21-33.

18. Demartini JD, Pattathil S, Miller JS, Li H, Hahn MG, Wyman CE. Investigating plant cell wall components that affect biomass recalcitrance in poplar and switchgrass. Energy Environ Sci. 2013;6(3):898-909.

19. Segal L, Creely JJ, Martin AE Jr, Conrad CM. An empirical method for estimating the degree of crystallinity of native cellulose using the X-Ray diffractometer. Text Res J. 1959;29(10):786-94.

20. Lee HR, Kazlauskas RJ, Park TH. One-step pretreatment of yellow poplar biomass using peracetic acid to enhance enzymatic digestibility. Sci Rep. 2017;7(1):12216.

21. Gustafsson J, Ciovica L, Peltonen J. The ultrastructure of spruce kraft pulps studied by atomic force microscopy (AFM) and X-ray photoelectron spectroscopy (XPS). Polymer. 2003:44(3):661-70.

22. Yang M, Wang J, Hou X, Wu J, Fan X, Jiang F, Tao P, Wang F, Peng P, Yang $F$, Zhang J. Exploring surface characterization and electrostatic property of Hybrid Pennisetum during alkaline sulfite pretreatment for enhanced enzymatic hydrolysability. Bioresour Technol. 2017;244(1):1166.

23. Chen $\mathrm{H}$, Liu L. Unpolluted fractionation of wheat straw by steam explosion and ethanol extraction. Bioresour Technol. 2007;98(3):666-76.

24. Kumar R, Mago G, Balan V, Wyman CE. Physical and chemical characterizations of corn stover and poplar solids resulting from leading pretreatment technologies. Bioresour Technol. 2009;100(17):3948-62.

25. Nakagame S, Chandra RP, Kadla JF, Saddler JN. The isolation, characterization and effect of lignin isolated from steam pretreated Douglas-fir on the enzymatic hydrolysis of cellulose. Bioresour Technol. 2011;102(6):4507-17.

26. Huang Y, Sun S, Huang C, Yong Q, Elder T, Tu M. Stimulation and inhibition of enzymatic hydrolysis by organosolv lignins as determined by zeta potential and hydrophobicity. Biotechnol Biofuels. 2017;1:10.

27. Donohoe BS, Decker SR, Tucker MP, Himmel ME, Vinzant TB. Visualizing lignin coalescence and migration through maize cell walls following thermochemical pretreatment. Biotechnol Bioeng. 2008;101(5):913-25.

28. Shinde SD, Meng X, Kumar R, Ragauskas AJ. Recent advances in understanding the pseudo-lignin formation in a lignocellulosic biorefinery. Green Chem. 2018;20:2192-205.

29. Li H, Pu Y, Kumar R, Ragauskas AJ, Wyman CE. Investigation of lignin deposition on cellulose during hydrothermal pretreatment, its effect on cellulose hydrolysis, and underlying mechanisms. Biotechnol Bioeng. 2014;111:485-92.

30. Kumar R, Hu F, Sannigrahi P, Jung S, Ragauskas AJ, Wyman CE. Carbohydrate derived-pseudo-lignin can retard cellulose biological conversion. Biotechnol Bioeng. 2013;110:737-53.

31. Pan X. Effect of acetyl groups on enzymatic hydrolysis of cellulosic substrates. Holzforschung. 2006;60(4):398-401.

32. Pu Y, Fan $H$, Fang $H$, Davison $B H$, Ragauskas AJ. Assessing the molecular structure basis for biomass recalcitrance during dilute acid and hydrothermal pretreatments. Biotechnol Biofuels. 2013;6:15.

33. Schneider L, Dong Y, Haverinen J, Jaakkola M, Lassi U. Efficiency of acetic acid and formic acid as a catalyst in catalytical and mechanocatalytical pretreatment of barley straw. Biomass Bioenergy. 2016;91:134-42. 
34. Shuai L, Amiri MT, Questell-Santiago YM, Héroguel F, Li Y, Kim H, Meilan R, Chapple C, Ralph J, Luterbacher JS. Formaldehyde stabilization facilitates lignin monomer production during biomass depolymerization. Science. 2016;354:329.

35. Shuai L, Questell-Santiago YM, Luterbacher JS. A mild biomass pretreatment using gamma-valerolactone for concentrated sugar production. Green Chem. 2016;18:937-43.

36. Mouthier T, Appeldoorn MM, Pel H, Schols HA, Gruppen H, Kabel MA. Corn stover lignin is modified differently by acetic acid compared to sulfuric acid. Ind Crop Prod. 2018;121:160-8.

37. Lai C, Yang B, He J, Huang C, Li X, Song X, Yong Q. Enhanced enzymatic digestibility of mixed wood sawdust by lignin modification with naphthol derivatives during dilute acid pretreatment. Bioresour Technol. 2018;269:18-24

38. Wi S, Cho E, Lee D, Lee S, Lee Y, Bae H. Lignocellulose conversion for biofuel: a new pretreatment greatly improves downstream biocatalytic hydrolysis of various lignocellulosic materials. Biotechnol Biofuels. 2015;8:228.

39. Song Y, Wi SG, Kim HM, Bae H-J. Cellulosic bioethanol production from Jerusalem artichoke (Helianthus tuberosus L.) using hydrogen peroxideacetic acid (HPAC) pretreatment. Bioresour Technol. 2016;214:30-6.

40. Chundawat SP, Venkatesh B, Dale BE. Effect of particle size based separation of milled corn stover on AFEX pretreatment and enzymatic digestibility. Biotechnol Bioeng. 2007;96(2):219-31.

41. Luo M, Tian D, Shen F, Hu J, Zhang Y, Yang G, Zeng Y, Deng S, Hu Y. A comparative investigation of $\mathrm{H}_{2} \mathrm{O}_{2}$-involved pretreatments on lignocellulosic biomass for enzymatic hydrolysis. Biomass Convers Biorefin. 2018. https:// doi.org/10.1007/s13399-018-0364-0.

42. Andrić P, Meyer A, Jensen P, Dam-Johansen K. Reactor design for minimizing product inhibition during enzymatic lignocelluloses hydrolysis: I. Significance and mechanism of cellobiose and glucose inhibition on cellulolytic enzymes. Biotechnol Adv. 2010;28(3):308-24.

43. Kumar R, Wyman CE. Strong cellulase inhibition by mannan polysaccharides in cellulose conversion to sugars. Biotechnol Bioeng. 2014;111:1341-53.

44. Dąbkowska K, Alvarado-Morales M, Kuglarz M, Angelidaki I. Miscanthus straw as substrate for biosuccinic acid production: focusing on pretreatment and downstream processing. Bioresour Technol. 2019;278:82-91.

45. Chen X, Xin D, Wang R, Qin Y, Wen P, Hou X, Zhang J. Factors affecting hydrolytic action of xylanase during pennisetum saccharification: role of cellulose and its derivatives. Ind Crop Prod. 2019;130:49-56.

46. Yang M, Zhang A, Liu B, Li W, Xing J. Improvement of cellulose conversion caused by the protection of Tween-80 on the adsorbed cellulase. Biochem Eng J. 2011;56(3):125-9.

47. Kumar R, Wyman CE. Effect of additives on the digestibility of corn stover solids following pretreatment by leading technologies. Biotechnol Bioeng. 2009;102:1544-57.

48. Sun Q, Foston M, Meng X, Sawada D, Pingali S, O'Neill H, Li H, Wyman C, Langan P, Ragauskas A, Kumar R. Effect of lignin content on changes occurring in poplar cellulose ultrastructure during dilute acid pretreatment. Biotechnol Biofuels. 2014:7:150.
49. Bhagia S, Kumar R, Wyman CE. Effects of dilute acid and flowthrough pretreatments and BSA supplementation on enzymatic deconstruction of poplar by cellulase and xylanase. Carbohydr Polym. 2017;157:1940-8.

50. Muurinen El, Sohlo JJK. Simulation of recovery methods for pulping with peroxyformic and peroxyacetic acids. Comput Chem Eng. 1994;18:S609-13.

51. Zhao X, Wu R, Liu D. Production of pulp, ethanol and lignin from sugarcane bagasse by alkali-peracetic acid delignification. Biomass Bioenergy. 2011:35:2874-82.

52. Abdulrahman $A$, van Walsum $G P, U m B$ BH. Acetic acid removal from prepulping wood extract with recovery and recycling of extraction solvents. Appl Biochem Biotechnol. 2019;187(1):378-95.

53. Sluiter A, Hames B, Ruiz R, Scarlata C, Sluiter J, Templeton D, Crocker D. Determination of structural carbohydrates and lignin in biomass. Golden: National Renewable Energy Laboratory; 2008.

54. Ghose TK. Measurement of cellulase activities. Pure Appl Chem. 1987;59:257-68.

55. Bailey MJ, Nevalainen $\mathrm{KMH}$. Induction, isolation and testing of stable Trichoderma reesei mutants with improved production of solubilizing cellulase. Enzyme Microb Technol. 1981;3(2):153-7.

56. Lowry OH, Rosebrough NJ, Farr AL, Randall RJ. Protein measurement with the Folin phenol reagent. J Biol Chem. 1951;193:265-75.

57. Montplaisir D, Daneault C, Chabot B. Surface composition of grafted thermomechanical pulp through XPS measurement. BioResources. 2008;3(4):1118-29.

58. Li Y, Qi B, Luo J, Wan Y. Effect of alkali lignins with different molecular weights from alkali pretreated rice straw hydrolyzate on enzymatic hydrolysis. Bioresour Technol. 2016;200:272-8.

59. Gessner A, Waicz R, Lieske A, Paulke B, Mäder K, Müller RH. Nanoparticles with decreasing surface hydrophobicities: influence on plasma protein adsorption. Int J Pharm. 2000;196(2):245-9.

60. Xu Y, Li F, Wang X, Yong Q, Yu S. Simultaneous separation and quantification of linear xylo- and cello-oligosaccharides mixtures in lignocellulosics processing products on high-performance anion-exchange chromatography coupled with pulsed amperometric detection. BioResources. 2013;8(3):3247-59.

61. Overend RP, Chornet E, Gascoigne JA. Fractionation of lignocellulosics by steam-aqueous pretreatments. Philos Trans R Soc Lond A Math Phys Eng Sci. 1987;321(1561):523-36. https://doi.org/10.1098/rsta.1987.0029.

62. Seesuriyachan P, Kawee-ai A, Chaiyaso T. Green and chemical-free process of enzymatic xylooligosaccharide production from corncob: enhancement of the yields using a strategy of lignocellulosic destructuration by ultra-high pressure pretreatment. Bioresour Technol. 2017;241:537-44.

63. Surek E, Buyukkileci AO. Production of xylooligosaccharides by autohydrolysis of hazelnut (Corylus avellana L.) shell. Carbohydr Polym. 2017:174:565-71.

Ready to submit your research? Choose BMC and benefit from

- fast, convenient online submission

- thorough peer review by experienced researchers in your field

- rapid publication on acceptance

- support for research data, including large and complex data types

- gold Open Access which fosters wider collaboration and increased citations

- maximum visibility for your research: over $100 \mathrm{M}$ website views per year

At BMC, research is always in progress.

Learn more biomedcentral.com/submissions 